\title{
Muhammadiyah's Framework on The Community Economic Empowerment
}

\author{
Imamul Hakim \\ Program Studi Ekonomi Syariah, Fakultas Agama Islam, \\ Universitas Muhammadiyah Malang \\ E-mail: imamulhakim@umm.ac.id
}

\begin{abstract}
The contribution of Muhammadiyah in the field of economic empowerment in the community still does not seem real. The study of the concept of community economic empowerment based on religious, social organisations needs to be done to find a more effective approach. This study aims to examine the ideas or conceptual ideas of economic empowerment from Muhammadiyah Scholars and from Muhammadiyah Structural which have been written in the published form so that the meeting point can be found in an effective format of community economic empowerment. This study uses a library approach. The results in the research are grouped into two sources of economic empowerment concept ideas, namely; the concept from Muhammadiyah intellectuals and the concept from Structural Muhammadiyah. Firstly, from the perspective of Muhammadiyah scholars emphasising the full Structural involvement of Muhammadiyah in empowering the community's economy by fostering, mentoring and developing, building a network of entrepreneurs, business networks and distribution networks, played a role as a mediator between Muhammadiyah member entrepreneurs. Secondly, the concept of community economic empowerment in the perspective of Muhammadiyah Structural, there is not much difference with the first idea, but more emphasises the development of Muhammadiyah's Economic network and its members and focuses on economic empowerment at the branch level.
\end{abstract}

Keywords: Muhammadiyah, Economics, Community, Development. 


\begin{abstract}
ABSTRAK
Kontribusi Muhammadiyah di bidang pemberdayaan ekonomi di masyarakat masih belum tampak nyata. Studi tentang konsep pemberdayaan ekonomi masyarakat berdasarkan agama, organisasi sosial perlu dilakukan untuk menemukan pendekatan yang lebih efektif. Penelitian ini bertujuan untuk menguji ide-ide atau ide-ide konseptual pemberdayaan ekonomi dari Cendekiawan Muhammadiyah dan dari Struktural Muhammadiyah yang telah ditulis dalam bentuk yang diterbitkan sehingga titik pertemuan dapat ditemukan dalam format pemberdayaan ekonomi masyarakat yang efektif. Penelitian ini menggunakan pendekatan perpustakaan. Hasil dalam penelitian dikelompokkan ke dalam dua sumber ide konsep pemberdayaan ekonomi, yaitu; konsep dari intelektual Muhammadiyah dan konsep dari Struktural Muhammadiyah. Pertama, dari perspektif para cendekiawan Muhammadiyah yang menekankan keterlibatan struktural penuh Muhammadiyah dalam memberdayakan ekonomi masyarakat dengan membina, membimbing dan mengembangkan, membangun jaringan wirausahawan, jaringan bisnis, dan jaringan distribusi, berperan sebagai mediator antara wirausahawan anggota Muhammadiyah. Kedua, konsep pemberdayaan ekonomi masyarakat dalam perspektif Struktural Muhammadiyah, tidak ada banyak perbedaan dengan gagasan pertama, tetapi lebih menekankan pengembangan jaringan Ekonomi Muhammadiyah dan anggotanya dan berfokus pada pemberdayaan ekonomi di tingkat cabang.
\end{abstract}

Kata Kunci: Muhammadiyah, Economi, Komunitas, Pemberdayaan.

\title{
1. Introduction
}

Poverty in Indonesia seems to be an acute problem that has never been resolved. Poverty alleviation programs by the government cannot exclude them from the demands of the basic needs they need. Government policies appear to be merely the realisation of work programs as a consequence of campaign promises, even worse is that aid programs for the poor are used as political tools for campaigning. Such methods are so that the programs are not able to touch the real problem. Not to mention the acute problem of corruption that has plagued this nation like a chronic illness that cannot be cured, Corruption is sweeping almost in all lines of this nation, not only by Personal, but corruption has been carried out together, they even protect each other. The result is that we as a nation that has long been independent, but that independence cannot be felt by most of its people. Many people are slaves to entrepreneurs (cukong), both those who work on 
plantations, households and those who are traded as commercial sex workers. Besides, many poor people live under very miserable suffering; they are not only homeless but also have difficulty just fulfilling their food needs.

The problem above is very contradictory to the status of this country, as a country with abundant natural wealth should be able to be utilised as well as possible to be able to prosper the lives of its people. With abundant natural wealth, it can also provide decent employment and income opportunities so that they can lift their ranks from suffering and poverty. However, what happened, they lived in poverty. Such conditions if allowed to drag on, with increasing population growth, will inherit various social problems, including increased crime rates and poverty rates.

It is undeniable that poverty is one of the causes of Mungkar, as stated by the Prophet Muhammad in a hadith fragment "poverty will draw closer to Mungkar" ... poverty can make people's reasons to do things that are not justified by religion such as stealing, cheating, robbing and so on, even poverty can force people to sell faith to fulfil their needs and demands for life.

By increasing the economic well-being of the people, they will make them more dignified and can distance the people from kufr and then can do good by helping each other. Because removing them from the demands of basic need is a tool to prevent the occurrence of Mungkar by increasing welfare standards and meeting their basic needs. Therefore, freeing society on poverty and slavery is an obligation for Muhammadiyah, as a manifestation of the ideals of the founders of Muhammadiyah. Muhammadiyah as an Islamic organisation is required to be able to realise the contents of the messages of the Qur'an and Hadith in solving the problems of poverty and oppression so that Muhammadiyah can create a spiritual presence in people's lives. The involvement of religious organisations in Indonesia such as Muhammadiyah is very needed in the field of economic empowerment, given the success of the nation's history can not be separated from the vital role of Muhammadiyah. It is time for Muhammadiyah through its social assets to manage the economy in a congregation to progress together and provide significant contributions to this nation through the economic empowerment movement as it plays in the field of education (Hakim, 2018). Muhammadiyah has a relatively large number of members that are widespread from urban areas to rural areas throughout the country. Most members of Muhammadiyah are relatively well educated, and many are engaged in business. Building networks and cooperating with third parties is relatively easy and quite extensive. Muhammadiyah has the potential for the high demand for goods and services from its members and Charity Business to be able to support the Muhammadiyah economic empowerment movement (Hamid in Jatmiko, 2010).

In empowering the community economy, it is necessary to strive for hard work and creative efforts in finding a model of economic movement approach based on religious and community organisations that is more effective and 
efficient in empowering the community economy by considering geographical sectors, community income patterns, economic potential and others. Therefore, the format of community economic empowerment that is appropriate with the sociological conditions of the community will significantly influence the success of economic empowerment.

\section{Literature Review}

\subsection{Empowerment}

According to Karsidi (2001), community empowerment is an effort to motivate and encourage people to be able to explore their potential and improve their quality of life through education for their self-awareness and ability. Whereas Community Empowerment according to Andriany (2015) can be interpreted as a process that builds people or society through developing community capabilities, changing community behaviour, and organising communities. With the primary goal in community empowerment, namely developing community capacity, changing people's behaviour, and organising the community. Many community abilities can be improved, such as the ability to do business, the ability to find information, the ability to manage activities, capabilities in agriculture and many more according to the needs or problems faced by the community.

Specifically, the empowerment goals are classified by Tjokrowinoto in Christie (2012) which is formulated in 3 (three) fields namely; economic, political and socio-cultural. Empowerment activities must be carried out in a comprehensive manner covering all aspects of people's lives to liberate groups of people from the dominance of power which includes the fields of economy, politics and socio-culture. Meanwhile, empowerment in the economic field according to Mangifera (2018) is a series of activities to increase assets and capabilities to be willing and able to access various resources, capital, technology and markets with an approach to assistance, capacity building, service and defence towards community independence. Empowerment is directed at improving the economy of the community productively to produce high added value and greater income. The goal to be achieved from empowerment is to form individuals and communities to become independent; such independence includes economic, thinking, acting and controlling what they do.

According to Prasetyo \& Maisaroh (2009), the concept of empowerment has changed the Concept of economic and social development which is at the same time able to explain how to alleviate poverty, especially in rural areas that have a productive and creative potential for microeconomics, based on creative 
resources of the poor. Whereas according to $\mathrm{Nu}$ Graha (2006) economic empowerment is intended to shape the ability of people, especially vulnerable and weak groups to have access to productive resources that enable them to increase their income and obtain goods and services they need and participate in the development process and decisions that affect them. However, he emphasises that in reality often the process does not appear automatically, but grows and develops based on the interaction of the local community with outside parties or social workers both working on a charity and professional perspective.

In this regard, Suparman (2012) suggests the need for ongoing collaborative action on the government, business sector, NGOs, CBOs, academia, and audiences that are urgently needed to create more inclusive and equitable development. Islamic Unity (Persis), Nahdhatul Ulama ( NU) and Muhammadiyah are one of the Islamic community organisations and religious organisations that function as social organisations, and their existence can be challenged to promote a better social role in the economic, social and cultural fields. In the economic field, these three organisations are required to play a real role in inspiring economic progress.

\subsection{Muhammadiyah and Economic Empowerment}

In Muhammadiyah, the figure of the Movement for Empowerment is in the figure of KH. Ahmad Dahlan was able to respond to his current challenges quickly and precisely through the Tajdid Movement (renewal) in the fields of education, da'wah, and empowerment of Indonesian society at that time (El-Ali, 2016). It is time for Muhammadiyah as an organisation not only to be engaged in social, education and worship practices but also in business and finance. At least, there are two reasons why Muhammadiyah can play a role in business practices. First, Muhammadiyah deserves to play a role in the business field because of the benefits that can be exchanged with the institutions it has, such as schools, hospitals or other religious preaching institutions. Second, Muhammadiyah can sustain its potential strength to organise the business. It is supported by the fact that many government officials sit in Muhammadiyah's organisational structure, the number of human resources produced by Muhammadiyah schools, the large number of businesses and the many members they have (Setyawan, 2013).

Muhammadiyah as a religious organisation, in this case, is not only an active subject of civil society but represents Islam as a social force that plays an active role in the process of social change including sustainable development (Rahmanto \& Rozikan). With its roots in the tradition of thought, the Muhammadiyah movement is thicker with the community empowerment movement as a structural accumulation and social imbalance from the arrogance of development. The idea of Development that develops at this time is not only to realise justice and prosperity on the one hand but the development ideology that 
exists today deliberately maintains real social inequality and poverty in society (Muksin, 2016).

In the empirical shutter, according to Haerisma's study (2015), to increase the productivity of the Economic and Entrepreneurship Assembly (MEKM) program, the network strategy in the form of horizontal network development with private parties, the government, universities, community institutions, and mass organization There are several activities that have been carried out by cooperating with various parties to develop economic and entrepreneurship programs, including establishing a relationship with LAZISMU in collecting and distributing zakat, infaq, alms and endowments. The collected funds from internal and external donations are distributed by LAZISMU to various programs, including; the field of education for scholarships, assisting the welfare of honorary teachers and economics by helping productive needs for business for members of Muhammadiyah with provisions for profit sharing.

In its efforts to empower the community, 'Aisyiyah has a Qoryah Thayyibah (QT) program held in Potorono, Banguntapan, Bantul, DIY. This program aims to realise the lives of people who are more prosperous and independent by emphasising religious aspects as the core of all activities. This program has six plans, namely; religion, economics, education, health, community social and Sakinah family (Miftahulhaq, 2017). He also explains that the QT Program is a multidimensional and integrated missionary program that makes the religious aspect of the main program. In general, this program makes the community able to solve problems independently so that the QT program has provided the impetus for efforts to create a better life and improve welfare.

\section{Muhammadiyah Economic Empowerment Movement}

The format of the Muhammadiyah Economic Empowerment Movement can generally be divided into two sources of great ideas, namely: first, the perspective of the thoughts of Muhammadiyah leaders and scholars, and second, the view of the Muhammadiyah Central Executive structure.

From the perspective of the thinking of leaders and scholars, there have been many excellent ideas about the Muhammadiyah economic empowerment movement. They are very concerned about the community empowerment movement especially using an approach based on religious, social organisations. According to them, Muhammadiyah as a Religious Social Organisation should play role itself in community economic empowerment as an effort to free the public from oppression and poverty. The success that Muhammadiyah has played in empowerment in the fields of education and health is expected to be able to be realised in the economic field.

On the other hand, from the view of the Muhammadiyah Central Executive structure, the Muhammadiyah Economic Empowerment Movement has actually manifested itself in the Economics and Entrepreneurship Mission (MEKM) which 
has its management from the central level to the branch, which is also supported by Ortom Muhammadiyah (autonomous organizations) such as Aisyiayah, Nasyiatul Aisyiyah, Pemuda Muhammadiyah in the form of a main program namely community economic empowerment which is fostered in the development of entrepreneurship and small businesses through the development of human resources of business people. Besides, Muhammadiyah also established a cooperative and Baitul Mal Muhammadiyah as a means of financing and developing small businesses (Hakim, 2018).

\subsection{Scholar's Perspectives on the Muhammadiyah Economic Empowerment Movement}

For Muhammadiyah, the source of financial income from business activities is necessarily an essential part of facilitating the Muhammadiyah movement to achieve its objectives. According to Raharjo (2000), Muhammadiyah should not only appeal to their social responsibility to be able to finance da'wah and charitable organisations to provide social services to the ummah. However, Muhammadiyah does not carry out economic development for its members. On the other hand, according to Asy'arie (2000), Muhammadiyah economic movement must also have an impact on the economic empowerment of its citizens, in an effort to create business opportunities and overcome the growing problem of unemployment, and increasing poverty can threaten the existence of faith ( $k \bar{a} d a$ al fakru an yakuna kufran).

Based on the pattern of the community empowerment movement in Muhammadiyah, there will be a more prominent pattern of movement, namely in the fields of social, education and health. On the other hand, the empowerment model in the economic field has not yet been prominent in the Muhammadiyah movement. But if Muhammadiyah learns from experience in education and health, according to Fadjar (2010), the role of Muhammadiyah as an economic movement will be more meaningful if initiated and confirmed as a social network with market opportunities, business training, capital and information centres. Financial management as well as business innovations that become the binding and building of togetherness among economic business actors of the Muhammadiyah members. This role will encourage business empowerment of Muhammadiyah Members as well as pillars to build the nations economic independence. This choice is far more strategic than just trying to make a futile intervention and experimenting organizationally to manage and control its own economic and business activities.

He explains that Muhammadiyah as a social movement has a broad meaning including intention and endeavour to build a business economic movement that is oriented towards empowering and strengthening the people's 
economy. It is the social capital of Muhammadiyah members to strengthen and reaffirm their work in the field of business economics in line with the goal of developing progressive Islam. The Muhammadiyah Economic Empowerment Movement should be able to be a driver of the growth of business empowerment among Muhammadiyah citizens.

Relating to the role of Muhammadiyah in empowering the community economy, Mulkhan (2000) holds that in the economic empowerment of the community there needs to be structural involvement of Muhammadiyah. If there is no structural guarantee, he illustrates that giving opportunities to develop entrepreneurship naturally fosters productive economic activities for the lower class, but without Structural warranties, it is like releasing small children in the traffic chaos in the middle of the city. According to Mulkhan, the economic empowerment of the community requires guidance and assistance from various parties and guarantees economic protection from the government which is not only for large industries but also for the lower classes. Supriyono (2009), provides confirmation of the need for involvement and structural role of Muhammadiyah in empowering the community's economy, there are steps that must be made by the Muhammadiyah leadership namely; first, the Economic Assembly is required to cooperate with the Basic and Secondary Education Council (DIKDASMEN) and the Higher Education Council (DIKTI) to create a program to foster an entrepreneurial spirit towards the Muhammadiyah young generation that starts from school age. The second is making a coaching and learning program in increasing the growth of entrepreneurs through education and training for teachers. Third, improve the performance of Muhammadiyah entrepreneurs, both pioneers and those who already have a business or who have been successful by providing access to market opportunities, cooperation and financial access. Abimanyu (2000), added that community economic empowerment also requires government support in the form of a business climate and regulations that make it possible for them to gain banking and market access. Healthy banking and sharia principles (profit sharing and losses) are needed by the people's economy based on MSMEs (UMKM).

Supriyono (2009) further explained about structural involvement in the program to increase the growth and performance of entrepreneur members of Persyarikatan Muhammadiyah by grouping it into two; First, entrepreneurs who are pioneering, the Economic Council can facilitate their relationship with their seniors for the learning process and business growth. Build synergies for them to capture greater market opportunities. Even a program is needed that can help them gain financial access to business development. Second; successful entrepreneurs, Persyrikatan Muhammadiyah need a program to provide a conducive environment. An environment that can encourage them to stay focused in developing business from the National to the Global class. At this level, expansion is not solely for making money. Their financial needs have been fulfilled. So, it is 
necessary to motivate growth based on the values of Aqidah to be more beneficial for others. The ability to manage business needs to be continuously developed to enlarge the company.

In addition to the above, the need for structural involvement in building business networks among Muhammadiyah citizens is essential. According to Andjasmoro (2009), until now there have been many businesses in the real sector and finances both possessed by Muhammadiyah citizens personally and possessed by Muhammadiyah or a combination of ownership between Muhammadiyah and Muhammadiyah members. Muhammadiyah needs to assemble these economic units to become one of Muhammadiyah's economic strengths. It is necessary to establish a commercial network development centre between these business units.

\subsection{Structural's Perspectives on the Muhammadiyah Economic Empowerment Movement}

The program established in the organizational meetings at the central level to the lowest level has never forgotten to formulate strategic steps in economic empowerment, especially small and medium micro enterprises (MSMEs), which at the application level are mandated to the Economic and Entrepreneurship Council (MEKM), supported by all Ortom is like Aisyiyah with his Economic Council, Nasyiatul Aisyiyah with his Economic Department. All rely on the main program, namely the economic empowerment of the people which includes the development of human resources for business people, entrepreneurship development and small businesses, cooperatives / productive Baitut Tamwil Muhammadiyah (BTM) and Muhammadiyah Enterprises (BUMM) (Asnifati, 2009).

The implementation of economic empowerment programs that have been carried out by structural Muhammadiyah in Asnifati's perspective explains that Muhammadiyah uses a pattern of economic empowerment movements starting from the lower level (bottom up). Nelly further explained that three paths had been carried out in parallel by Muhammadiyah, namely: (1) Establishment and management of Muhammadiyah Enterprises (BUMM). (2) The Guidance, assistance and network expansion for Muhammadiyah business people by conducting training, business meetings, and mentoring for MSME groups. (3) Development of economic activities through existing business charities. (4) Businesses in the form of limited companies (PT), all Muhammadiyah citizens who are interested are allowed to invest in shares (Asnifati, 2009).

From the conceptual side, the following is the concept of community economic empowerment which was initiated by the Muhammadiyah Central Leadership:

\section{1) Branch Economic Development}

The concept of this branch-level economic development was taken and concluded from the Muhammadiyah Branch Member Economic Development 
(Pengembangan Ekonomi Anggota Ranting Muhammadiyah) Guide book published by the Branch Development Department (LPCR), Muhammadiyah Central Leadership in 2013. This book is a guide to the economic empowerment program at the Muhammadiyah Branch. Muhammadiyah Branch as the front guard who has direct contact with the community, so that it plays a very strategic role to facilitate and dynamise the business of members of the community or the community within the working area of the branch. In general, the Muhammadiyah Branch economic empowerment program can be summarised as follows: (a) Providing coaching, guidance and direction to Branch Members to start a business by providing training, skills and business practices. (b) As a business activity facilitator by providing understanding and experience on how to start a business to help find funding sources. (c) As a dynamic, the branch is expected to be able to act as a motivator. (d) Collecting businesses or entrepreneurs in the branch area becomes a unit that is interrelated and strengthens.

\section{2) Muhammadiyah Economic Network}

The Muhammadiyah Economic Network concept is contained in the book "The New Paradigm of Muhammadiyah (Revitalization of the Da'wah Movement with the Jami'ah System: Muhammadiyah Economic Network)" published by the Muhammadiyah Economic Development Council (MPEM). The Muhammadiyah Economic Network Concept has two objectives, namely the short term and the long steps mentioned as follows:

The short term objective of the Muhammadiyah Economic Network: 1) Providing benefits directly to network citizens. Network citizens are Muhammadiyah members in particular, and the ummah, in general, is incorporated into this network. 2) Strengthen organisational financing. This financing is obtained from community network contributions. 3) Improve the quality of the effectiveness and efficiency of managing business charities. 4) It is strengthening the bargaining power of the Ummah, in its position as a large enough consumer group, so that the ummah obtain an appropriate added value for goods/services produced by the producer. 5) Inviting external parties to utilise networks that have been formed jointly with network citizens (internal) in the form of further cooperation concerning: capital, business management, marketing, transportation and others.

The Long-term goals of the Muhammadiyah Economic Network, are as follows: 1) Raising potential strengths, activities and economic roles of the ummah both through the independence of network development or through cooperation with external parties. 2) Strengthening the resilience of business charity and business entities (revitalisation) in the Muhammadiyah environment. 3) Expanding business and employment opportunities for members of Muhammadiyah in particular and the ummah in general. 4) Growing new economic power, as a lesson in the development of Muhammadiyah's religious 
and social institutions in contributing to the realisation of civil, economic behaviour and strengthening Indonesia's macroeconomy.

Tabel 1.1

The functions and roles of the Muhammadiyah Economic Network

\begin{tabular}{|c|c|c|}
\hline Actor & Actors Formulation & Actor Function \\
\hline $\begin{array}{l}\text { Network } \\
\text { Service } \\
\text { Center }\end{array}$ & $\begin{array}{l}\text { An institution or } \\
\text { organisation that has a } \\
\text { mandate from } \\
\text { Persyarikatan to manage } \\
\text { the network as a whole. }\end{array}$ & $\begin{array}{l}\text { 1. Build, develop and empower networks. } \\
\text { 2. Making a "bargaining position" with } \\
\text { the producer } \\
\text { 3. Recording the entire 'database.' } \\
\text { 4. Establishing advanced cooperation } \\
\text { with producers }\end{array}$ \\
\hline Gateway & $\begin{array}{l}\text { Network elements that } \\
\text { have communication } \\
\text { facilities and that directly } \\
\text { serve network citizens }\end{array}$ & $\begin{array}{l}\text { Serving registration and inventory of } \\
\text { network membership (database), conveying } \\
\text { messages of goods/services needs of citizens } \\
\text { to the network, delivering messages of } \\
\text { supply and demand response from the } \\
\text { network to citizens, conducting transactions, } \\
\text { and helping distribution to network citizens, } \\
\text { and communicating between nodes }\end{array}$ \\
\hline Citizen & $\begin{array}{l}\text { Registered network } \\
\text { member }\end{array}$ & $\begin{array}{l}\text { Registering, identifying purchase needs, and } \\
\text { payments. }\end{array}$ \\
\hline Producer & $\begin{array}{l}\text { Produce goods/services } \\
\text { needed by the network }\end{array}$ & $\begin{array}{l}\text { Offer, fulfil requests, and provide the best } \\
\text { service and value for the network. }\end{array}$ \\
\hline
\end{tabular}

Source: MPEM Muhammadiyah Central Leader

\section{Conclusion}

There are two perspectives in the Muhammadiyah Economic Empowerment Concept which can be summarized as follows; first, the ideas of Muhammadiyah scholars who emphasized the full structural involvement of Muhammadiyah in empowering the community's economy by coaching, mentoring and developing, building a network of entrepreneurs, business 
networks and distribution networks, played the role of mediators between Muhammadiyah member entrepreneurs . Second, the concept of economic empowerment in the Muhammadiyah Structural perspective is not much different from the first idea, but it emphasises the development of Muhammadiyah's industrial network and focuses on economic empowerment at the branch level. Economic empowerment is focused on the branch level because the branch is the lowest level of the Muhammadiyah structure which becomes a force as a driver of Persyarikatan Muhammadiyah. Because of this, the branch level is the basis for coaching and empowering members. The Muhammadiyah branch as the front guard in contact with the community plays a very strategic role to facilitate and develop the business of Muhammadiyah members. The task of the Branch Manager in carrying out community empowerment programs is to provide coaching, guidance and direction, become a facilitator of members' business activities, play a role, as a business dynamic, and collecting businesses and entrepreneurs in the branch area to become a mutually reinforcing entity. Meanwhile, the development of the Muhammadiyah economic network is intended to empower production activities, strengthen the financing of economic activities, and increase the effectiveness and productivity of overall communication within the Muhammadiyah community.

\section{Bibliography}

Abimanyu, Anggito, 'Pemulihan Ekonomi Indonesia Dan Pemulihan Ekonomi Umat', in Meretas Jalan Baru Ekonomi Muhammadiyah, ed. by Amien Abdullah (Yogyakarta: Tiara Wacana, 2000), p. 74

Andjasmoro, Afghon, 'Manhaj Gerakan Ekonomi', in Memberi Dan Mencerahkan, ed. by Najib Hamid (Surabaya: Hikmah Press, 2009), pp. 129-33

Andriany, Dewi, 'Pengembangan Model Pendekatan Partisipatif Dalam Memberdayakan Masyarakat Miskin Kota Medan Untuk Memperbaiki Taraf Hidup', in SEMINAR NASIONAL EKONOMI MANAJEMEN DAN AKUNTANSI (SNEMA) FAKULTAS EKONOMI UNIVERSITAS NEGERI PADANG, 2015

Asnifati, Nelly, 'Pemberdayaan Ekonomi” Dalam Najib Hamid', in Memberi Dan Mencerahkan, ed. by Najib Hamid (Surabaya: Hikmah Press, 2009), pp. $135-41$

Asy'Arie, Musa, 'Konsep Gerakan Pengembangan Ekonomi Persyarikatan Muhammadiyah', in Meretas Jalan Baru Ekonomi Muhammadiyah, ed. by Amien Abdullah (Yogyakarta: Tiara Wacana, 2000), pp. 105-13

Christie, Sadono, Pengantar Teori Mikro Ekonomi (Jakarta: PT. Raja Grafindo Persada, 2012)

Dalmeri, 'REVITALISASI FUNGSI MASJID SEBAGAI PUSAT EKONOMI DAN DAKWAH MULTIKULTURAL', Walisongo, 22 (2014), 321-50

El-Ali, Anwar Nuris, 'Ahmad Dahlan Dan Pesantren: Gerakan Pembaharuan Pendidikan, Dakwah, Dan Pemberdayaan Masyarakat Di Indonesia', DIROSAT Journal of Islamic Studies, 1 (2016), 243-58 
Fatimah, Feti, 'Meningkatkan Kemampuan Anggota 'Aisyiyah Dalam Pemberdayaan Potensi Ekonomi Daerah Untuk Meningkatkan Kemandirian Diri Dan Kemajuan Amal Usaha Muhammadiyah Di Balung Jember', Jurnal Pengabdian Masyarakat Ipteks, 4 (2018), 65-76

Graha, Andi $\mathrm{Nu}$, 'PENGEMBANGAN MASYARAKAT PEMBANGUNAN MELALUI PENDAMPINGAN SOSIAL DALAM KONSEP PEMBERDAYAAN DI BIDANG EKONOMI', Jurnal Ekonomi MODERNISASI, 5 (2009), 117-26

Haerisma, Alvien Septian, 'Pola Pemberdayaan Ekonomi Umat Di Organisasi Masyarakat Muhammadiyah Kota Cirebon', Al Amwal, 7 (2015), 120-31

Hakim, Imamul, 'Kontekstualisasi Gerakan Dakwah Muhammadiyah Berbasis Ekonomi Jamaah', in Rebranding Muhammadiyah, Dialektika Otentitas Dan Perubahan Dalam Pemikiran Dan Gerakan Muhammadiyah (Malang: PSIF Universitas Muhammadiyah Malang, 2018), pp. 1-19

Istan, Muhammad, 'Pengentasan Kemiskinan Melalui Pemberdayaan Ekonomi Umat Menurut Persfektif Islam', Al Falah, 2 (2017), 81-99

Jatmiko, Rohmat Dwi, 'Menumbuhkan Gerakan Ekonomi Dan Bisnis Melalui Partnership Stratejik Amal Usaha Muhammadiyah', in Gerakan Ekonomi Muhammadiyah; Kajian Dan Pengalaman Empiris, ed. by Nazaruddin M. Fadjar, Ihyaul Ulum, and Widayat (Malang: UMM Press, 2010), pp. 121-34

Karsidi, Ravik, 'Paradigma Baru Penyuluhan Pembangunan Dalam Pemberdayaan Masyarakat', MEDIATOR, 2 (2001), 115-25

M. Fadjar, Nazaruddin, 'Strategi Gerakan Ekonomi BisnisMuhammadiyah', in Gerakan Ekonomi Muhammadiyah; Kajian Danpengalaman Empiris, ed. by Nazaruddin Malik Fajar, Ihyaul Ulum, and Widayat (Malang: UMM Press, 2010), pp. 105-20

Maisaroh, P. Eko Prasetyo dan Siti, 'Model Strategi Pemberdayaan Ekonomi Rakyat Sebagai Upaya Pengentasan Kemiskinan', Trikonomika, 8 (2009), $103-125$

Mangifera, Liana, 'Pemberdayaan Ekonomi Anggota Nasyiatul Aisyiyah Delanggu Melalui Pelatihan Kewirausahaan', in The National Conferences Management and Business (NCMAB), 2018

Miftahulhaq, 'Strategi Pelaksanaan Dakwah 'aisyiyah Melalui Pendekatan Pembangunan Masyarakat Lokal', JURNAL AL-HIKMAH, 3 (2017), 5-18

Muksin, Ucin, 'Kiprah Muhammadiyah Dalam Pemberdayaan Masyarakat Desa', Anida, 14 (2015), 372-86

Mulkhan, Abdul Munir, 'Moral Kenabian: Paradigm Intelektual Pembangunan', in Meretas Jalan Baru Ekonomi Muhammadiyah, ed. by Amien Abdullah (Yogyakarta: Tiara Wacana, 2000), pp. 27-48

Rahardjo, Dawam, 'Format Dan Strategi Pengembangan Ekonomi Muhammadiyah Dalam Melenium Ke Tiga', in Meretas Jalan Baru Ekonomi Muhammadiyah (Yogyakarta: Tiara Wacana, 2000), pp. 117-35

Rahmanto, Mukhlis, and Rozikan, 'Reintepretasi Islam Dan Pemberdayaan Masyarakat; Studi Kasus Majelis Pemberdayaan Masyarakat Muhammadiyah', 1-10

Setyawan, Dharma, 'Analisis Hubungan Ijtihad Dan Tajdid Pemikiran Ekonomi Terhadap Perkembangan Usaha (Studi Kasus Pada Amal Usaha Organisasi Masyarakat Muhammadiyah)', Jurnal EKONOMI ISLAM, 2 (2013), 105-34 
Suparman, Deden, 'KEWIRAUSAHAAN-SOSIAL BERBASIS ORGANISASI MASYARAKAT (ORMAS) (Studi Analisis Mengenai Pemberdayaan Ekonomi Ummat Atas Unit Usaha-Sosial Persis, NU, Dan Muhammadiyah Di Kabupaten Garut)', JURNAL ISTEK, VI (2012), 158-64

Supriyono, Imam, 'L1MH', in Memberi Dan Mencerahkan, ed. by Najib Hamid (Surabaya: Hikmah Press, 2009), pp. 143-46 